\title{
THE NORDIC COUNTRIES AND THEIR TAX SYSTEMS. HIGHER TAXES, HIGHER WEALTH?
}

\author{
Andrei Ionut Husman ${ }^{1}$ \\ Petre Brezeanu ${ }^{2}$
}

DOI: https://doi.org/10.31410/ERAZ.S.P.2019.57

\begin{abstract}
The issue of taxation in the context of an increasingly globalized economy and the constant need for economic development is one of the main points of interest for all countries' governments. Even if we discuss about the northern EU Member States (i.e. Sweden, Finland and Denmark) or about Norway (non-EU state), the Nordic countries are well-known for their rigid tax systems with high tax burden. However, these countries record a high level of economic development. In this respect, the questions arise: is possible to have a high tax burden and a high wealth/welfare? If yes, how is this possible? Therefore, through this paper, we aim to perform certain analyses regarding the fiscal pressure registered by these countries (using the level of direct and indirect taxes) and the economic development (measured through the GDP per capita) based on the data provided by the OECD statistics database and Eurostat database. Also, we will draw econometric models to determine the relationship between the variables used. We expect the results of the analyses to show the efficiency of the Nordic tax systems, more precisely, we expect that the high tax burden to be offset by a high wealth/welfare of the Nordic population.
\end{abstract}

Keywords: Nordic countries, tax systems, taxation, tax burden.

\section{INTRODUCTION}

T $\mathrm{t}$ is well-known that, lately, taxation and its effects have been a subject of maximum interest 1 among practitioners and academics. As regards the Nordic (Scandinavian) countries, they are known for their rigid tax systems with high tax burden. But, in the same time, these countries record a high level of economic development. Consequently, we note that these countries are in some way different from the other countries (either EU Member States or not), which can lead both academics and practitioners to be interested in analyzing these countries. Thus, by extending the questions mentioned above, other questions arise: whether it is possible to have a high tax burden and increased wealth? Does the tax burden affect or not the wealth of citizens? If yes, how?

Given the described context and the above-mentioned questions, we started in our analysis in order to identify the particularities of the tax systems applied by the Scandinavian countries, as well as the influence of the fiscal elements in the economic development, with an emphasis on the citizens' welfare expressed by the GDP growth per capita. This analysis can also be conclusive in determining the applicability of these systems to other countries, considering their effectiveness.

\footnotetext{
$1 \quad$ Bucharest University of Economic Studies, Romania

2 Bucharest University of Economic Studies, Romania
} 


\section{AIMS OF THE RESEARCH}

Through this paper, we aimed to achieve four main objectives. Firstly, we performed a precise summary of the studies relevant for our research given by the specialized literature. Further, in order to better understand the Scandinavian tax systems, we have synthesized the main methodologies and tax rates of these systems. Finally yet importantly, we designed certain econometric models using the following elements;

- dependent variable: the GDP per head of population expressed in annual growth rates (reflecting the wealth growth);

- independent variables: corporate income taxes, personal income taxes, social security contributions and VAT;

We used these elements registered by Denmark, Finland, Norway and Sweden for the period 1971-2017, based on the OECD public database.

\section{LITERATURE REVIEW}

The topic of taxation, or more precisely the tax burden is a predilection for researchers, given the fact that the taxation is an important instrument for collecting revenues to the state budget and the methodologies based on which the taxation is applied and its burden affect the wealth of citizens.

As already stated, the Nordic countries are well-known for their rigid tax systems with high tax burden. But, in the same time, these countries register a high level of economic development and these facts lead to several questions for researchers.

Starting in the 1950s, the researchers found no relationship between the tax elements and economic growth, relevant to this being the studies of Bloom (1955) and Thompson and Mattilda (1959). Similar results were obtained by the late 1980s, an example being the study of Carlton (1979).

However, after this period, the studies conducted by the researchers had different results, and the latest studies analyze and demonstrate the important links between taxation and economic growth. Thus, by performing a study at the level of 48 countries, Helms (1985) concluded that there is a significant negative impact of state and local taxes on economic growth. A certain correlation between the tax rates and GDP per capita was found in case of developing countries by Burgess and Stern (1993), while in the case of industrial countries the authors did not find any correlation between these elements.

Braşoveanu and Obreja (2008) also found that both distortionary and non-distortionary taxes have a negative impact on economic growth in Romania.

The results obtained by Romer and Romer (2010) indicate that an increase in tax burden with $1 \%$ leads to a decrease of the real GDP with approximative 3\%. Such results were also showed by Nálepová (2017), that concludes that at the level of OECD countries the income taxes affects in a negative way the economic growth and by Widmalm (2001) who conclude that at the level of 23 OECD countries the tax structure affects the economic growth in the sense that the personal income tax negatively affects the economic growth. Also, Widmalm (2001) found empirical evidence that the tax progressivity may be associated with low economic growth. The impact of certain taxation elements was also found by several authors such as Stoilova \& Patonov (2012) and Szarowská (2013). 
For the Nordic countries there are very few studies performed on the subject analyzed in this paper. However, for example, in their attempt to find the effects of taxation on the level and fluctuations of the household saving behavior, Kosketa \& Viren (1994) [12] concluded that in the Nordic countries a higher income taxation together with a lower unemployment rate accounted a lower level of household saving ratio. Further, the authors found that in Denmark, Finland, Norway and Sweden the fluctuations in the household saving ratio are affected by real income growth and by the inflation rate in a positive manner, while the real housing prices have a negative effect on household saving ratio.

Furthermore, Livingston (2016) [13] concluded that in the case of the Nordic model of taxation there is a "modestly" progressive taxation of individual income and a low level of taxation for passive income (dividend and capital gains). Also, the author states that the tax administration in Nordic countries is very sophisticated, with a high level of computerization.

A more recent study conducted by Stoilova (2017) [14] at the level of EU28 Member States proved that the government expenditure does not contribute to increasing the annual growth of GDP, while the total tax revenues appear to be less damaging to the economic growth, suggesting that the balanced budgets are growth-friendly. However, the author found that the Nordic countries (e.g. Denmark, Finland and Sweden) represent exceptions and they are registering the highest overall public spending and the highest tax burden (and also balanced budgets) in comparison with other EU countries. Another conclusion stated by Stoilova (2017) is that the economic growth may be supported by a tax structure based on selective consumption taxes, personal income taxes and property.

Given the above, the studies performed in this paper represent a reliable contribution to the existing literature and also can be a solid basis for further analysis in this field.

\section{RESEARCH METHODS}

Given the aims of the research described above, through this paper, we have contributed to the existent specialized literature with several analyzes on the level of Scandinavian countries that have specific tax systems.

In terms of research methods, the elements included are expressed as follows:

- GDP per head of population as growth rates ("GDPgr"): expressed in annual growth rates in percentage Corporate income taxes ("CIT"): in national currencies (millions) and which include taxes on income, profits and capital gains of corporates;

- Personal income taxes ("PIT"): in national currencies (millions) and including taxes on income, profits and capital gains of individuals;

- Employees' social security contributions ("SSC"): in national currencies (millions)

- VAT: in millions national currencies.

The analyses were based on the values of these indicators registered for the period 1971-2017.

Further, the econometric tools were used through the EViews 7 software and multiple regression models were projected and analysed using the data mentioned above.

Also, we used certain tax guides issued by the Big4 consultancy firm EY in order to highlight the taxation methodologies and rates in these countries. 


\section{TAX SYSTEMS OF NORDIC COUNTRIES}

Prior to the actual analyzes of the correlations between taxes an economic development, we should look at the characteristics of the Nordic tax systems. Therefore, based on the tax guides issued by EY [15] (based on the data available for 2018), we performed a synthesis of the tax systems (with an emphasis on tax rates) for the Nordic countries. This synthesis is presented in the Table 1 below.

As a side note, since the SSC were not included in the final econometric models designed, the table below does not contain the description of the SSC applied in these countries.

Table 1: Tax systems in Nordic countries

\begin{tabular}{|c|c|c|c|}
\hline CIT rate: $22 \%$ & CIT rate: $22 \%$ & CIT rate: $23 \%$ & CIT rate: $22 \%$ \\
\hline $\begin{array}{l}\text { VAT rates: } \\
\text { a) Standard: } 25 \% \\
\text { b) Zero rated } \\
\text { c) Exempt }\end{array}$ & $\begin{array}{l}\text { VAT rates: } \\
\begin{array}{l}\text { a) Standard: } 24 \% \\
\text { b) Reduced: } \\
\text { - } 10 \% \\
\text { - } 14 \% \\
\text { a) Zero rated } \\
\text { b) Exempt }\end{array}\end{array}$ & $\begin{array}{l}\text { VAT rates: } \\
\text { a) Standard:25\% } \\
\text { b) Reduced: } \\
\text { - } 12 \% \\
\text { - } 15 \% \\
\text { a) Zero rated } \\
\text { b) Exempt }\end{array}$ & $\begin{array}{l}\text { VAT rates: } \\
\text { a) Standard:25\% } \\
\text { b) Reduced: } \\
\text { - } 6 \% \\
\text { - } 12 \% \\
\text { a) Zero rated } \\
\text { b) Exempt }\end{array}$ \\
\hline $\begin{array}{l}\text { PIT: } \\
\text { - } 8 \% \text { mandatory la- } \\
\text { bor market tax on } \\
\text { all salary income } \\
+ \text { marginal income } \\
\text { and labor market } \\
\text { tax rates (approxi- } \\
\text { mative values): } \\
\text { - First } 50.000 \text { DKK: } \\
8 \% \\
\text { - Next } 492,283 \text { DKK: } \\
42 \% \\
\text { - Over } 542,283: 56 \%\end{array}$ & $\begin{array}{ll}\text { PIT: } & \\
\text { - } & \text { national tax: pro- } \\
& \text { gressive rates from } \\
& 0 \% \text { to } 31.25 \%+ \\
\text { - } & \text { municipal tax: flat } \\
& \text { rates that vary } \\
& \text { from } 16.5 \% \text { to } \\
& 22.5 \%+ \\
\text { - } & \text { church tax: flat } \\
& \text { rates that vary } \\
\text { from } 1 \% \text { to } 2.2 \%+ \\
\text { YLE tax (Public } \\
\text { broadcasting tax): } \\
\text { at a maximum of } \\
\text { 163 EUR per year }\end{array}$ & $\begin{array}{l}\text { PIT: } \\
\text { - general income tax: } \\
\text { a flat rate of } 23 \%+ \\
\text { personal income } \\
\text { tax: progressive } \\
\text { rates from } 0 \% \text { to } \\
15.4 \%\end{array}$ & \begin{tabular}{|cl} 
PIT: & \\
- & National tax: \\
- & $20 \%$ for income \\
& over 468,700 SEK \\
& up to SEK 675,700 \\
- & 25\% for income \\
& over 675,700 SEK + \\
- & Local taxes: rang- \\
& ing from $29 \%$ to \\
& $36 \%$
\end{tabular} \\
\hline
\end{tabular}

The tax systems of these countries are quite similar with corporate income tax rates of $22 \%$ or $23 \%$ and VAT rates of $25 \%$ or $24 \%$ (with similar reduced rates). These countries have a dual system of taxing the income of citizens, meaning that they apply progressive rates for the active income (salaries) and proportional tax rates for the passive income (capital income). Therefore, we can observe that these countries are very similar in terms of tax rates and tax methodologies. Also, the tax rates applied by these countries are above the EU average, hence the high level of the tax burden.

\section{EVOLUTION OF TAXATION AND ECONOMIC GROWTH}

As a further step in our research, in order to perform have an overview of the economic elements included in the analyzes and to be able to compare the evolution of these elements during the period analysed, in this chapter we include a graphical analysis and a short description of these evolutions.

The graphical analysis is splitted in two parts between the elements of taxation included (PIT, CIT, SSC and VAT) and the economic development (GDP_grate). 


\subsection{Evolution of taxation}

In the following figures are presented the evolutions of the tax elements for each country.

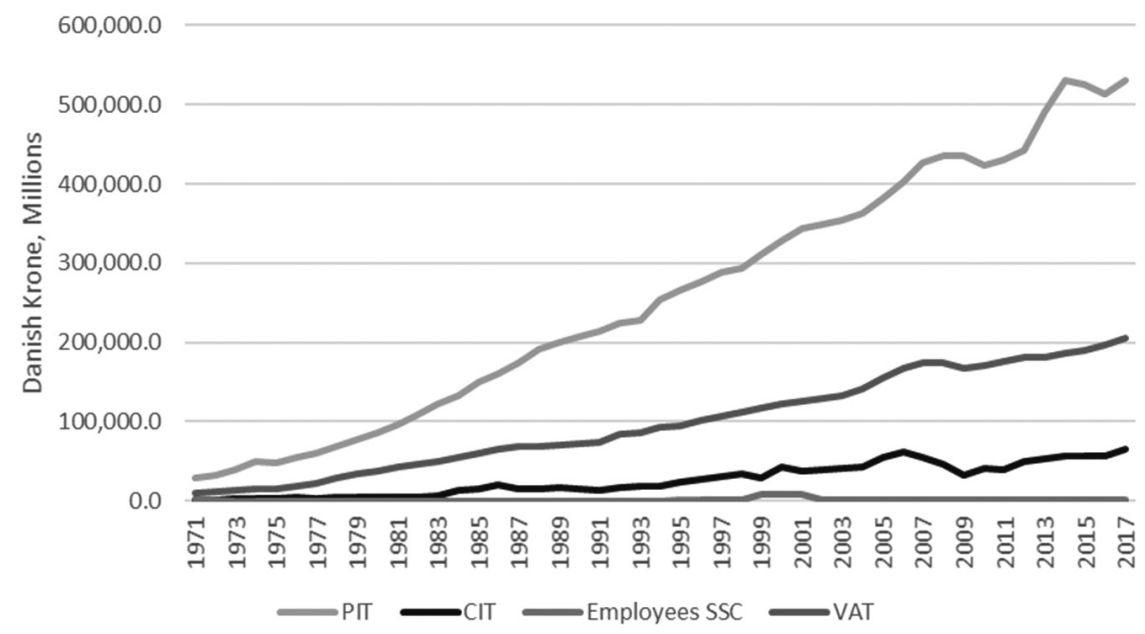

Figure 1: Taxation in Denmark (1971-2017)

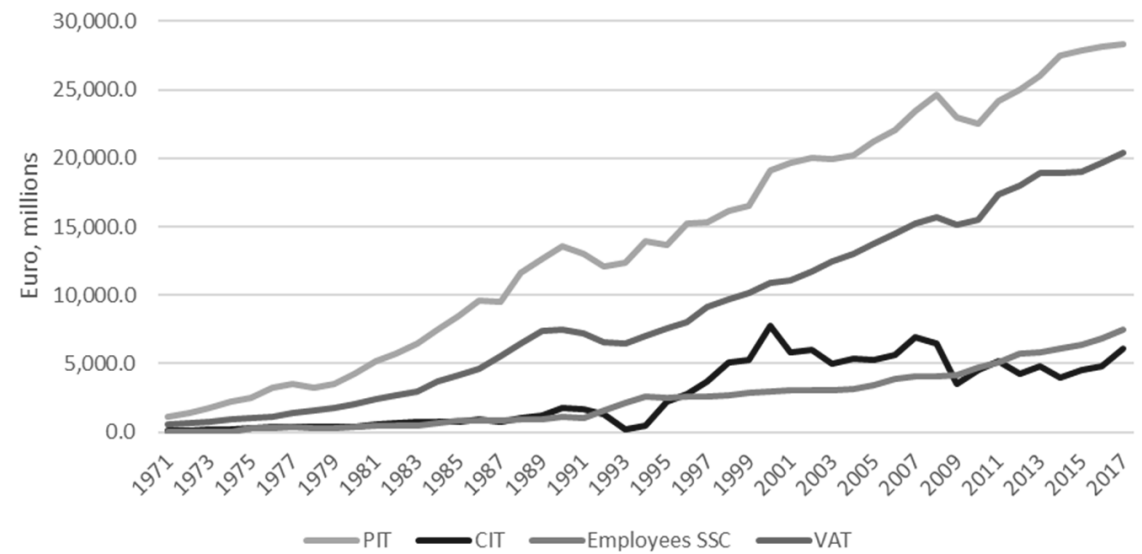

Figure 2: Taxation in Finland (1971-2017)

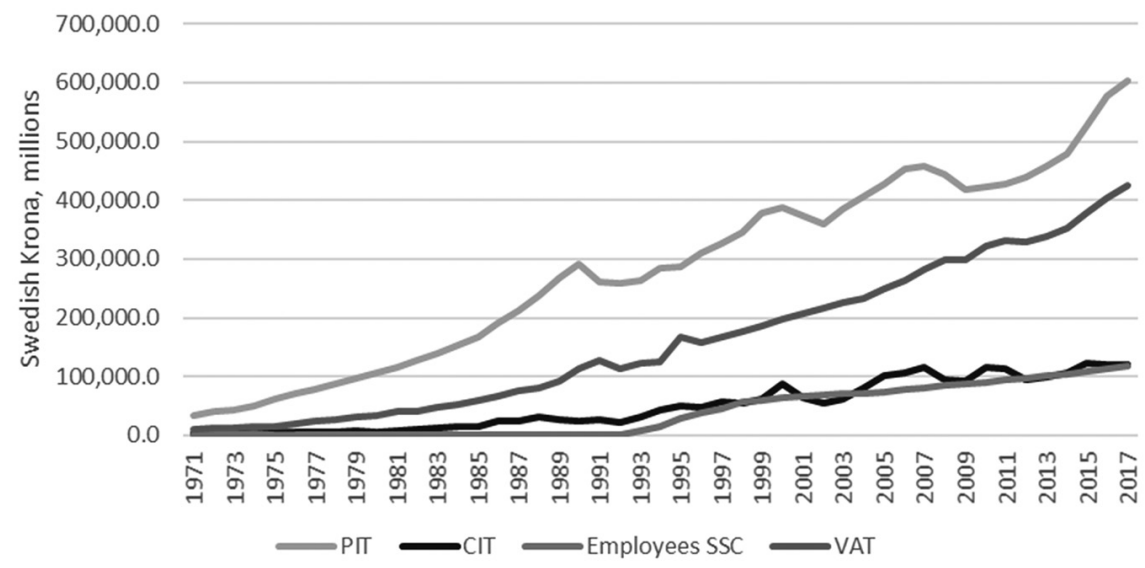

Figure 3: Taxation in Sweden (1971-2017) 


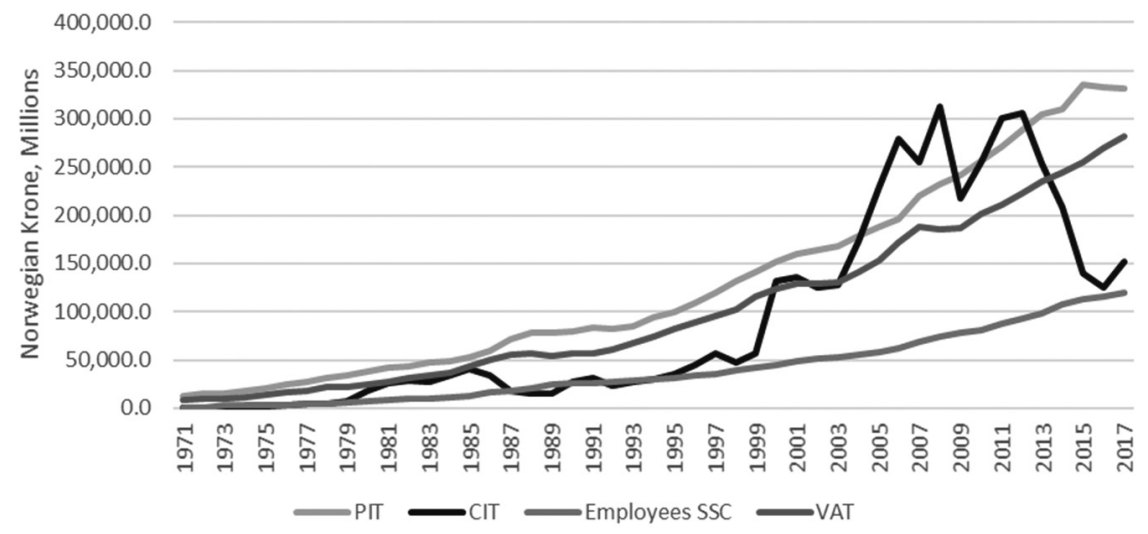

Figure 4: Taxation in Norway (1971-2017)

As we can observe in these graphics, the evolutions of taxation are similar in these countries with similar periods of decrease. We can see an exponential increase in cases of PIT, VAT and SSC. The volatility of CIT is very high in these countries, especially in Norway (which is not an EU country). The financial crisis started in 2008 affected all the countries and all the elements analyzed with the exception of SSC.

\subsection{Evolution of the economic development}

In the figures 5 to 8 below are presented the evolutions of the economic development expressed in annual growth rates of GDP per head of population for each country.

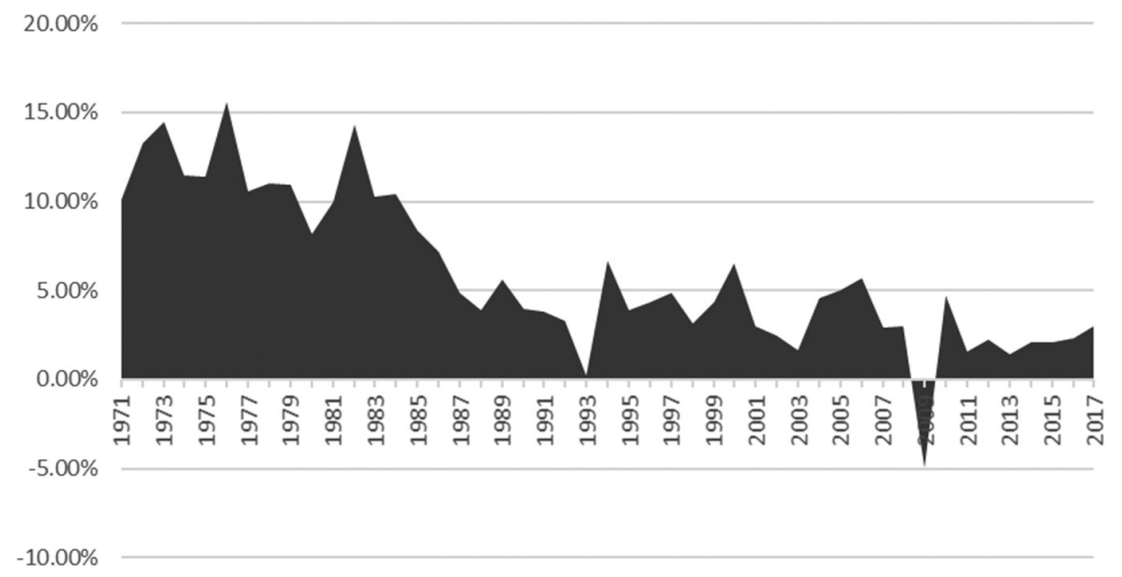

Figure 5: Evolution of the economic development in Denmark (1971-2017)

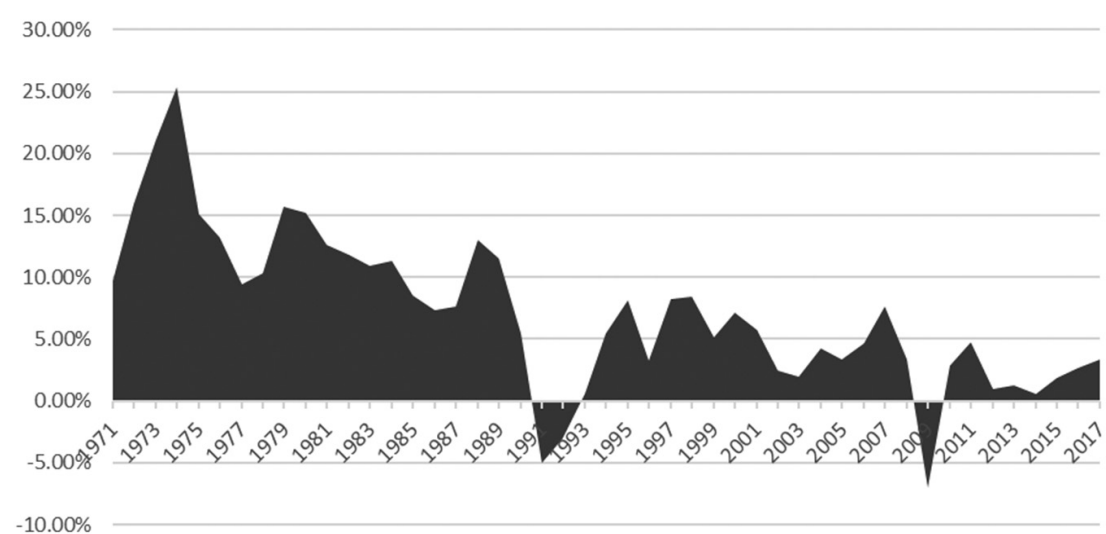

Figure 6: Evolution of the economic development in Finland (1971-2017) 


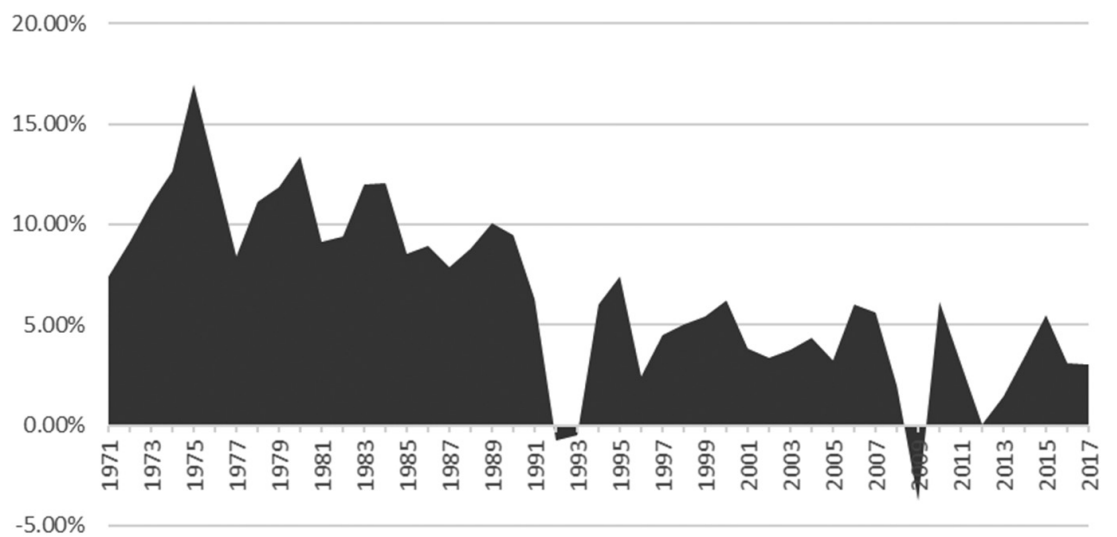

Figure 7: Evolution of the economic development in Sweden (1971-2017)

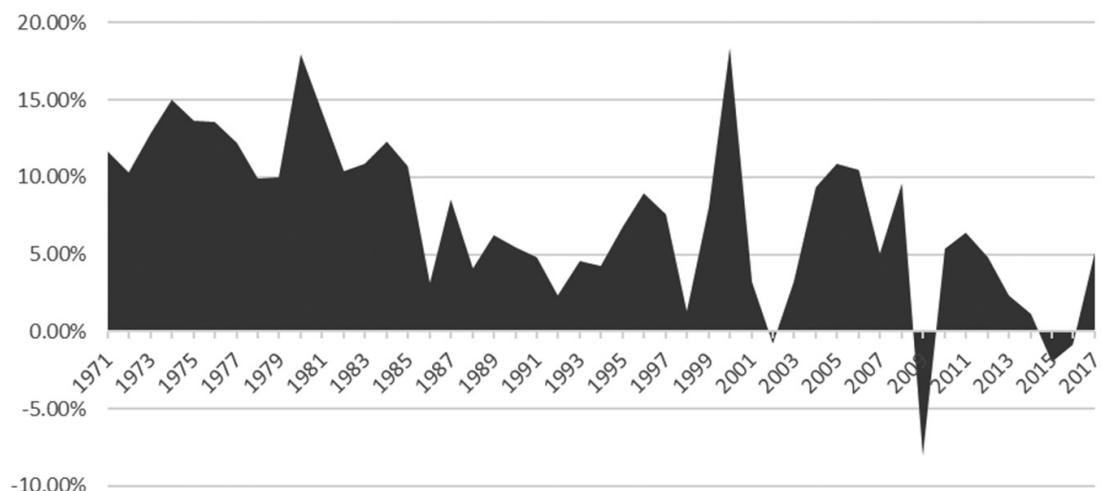

Figure 8: Evolution of the economic development in Norway (1971-2017)

Also, the economic development (expressed in GDP_grate) are similar in these countries, the same periods of decreases being registered over the 1990s, early 2000s and the last financial crisis (started in 2008).

\section{ECONOMETRIC RESULTS}

Going to the econometric results, the equation of the model from which we started is shown below:

$$
\text { GDP_grate }=\beta 0+\beta 1 \times \text { CIT }+\beta 2 \times \text { PIT }+\beta 3 \times \mathrm{SSC}+\beta 4 \times \text { VAT }+\beta 5 \times \mathrm{c}
$$

Following the tests made, the equations have been modified to obtain the most conclusive results from the econometric point of view for each country. In case of three of the four countries we proceeded to logarithm the independent variables in order to achieve a more relevant output.

Therefore, the outputs of the econometric models for each country are presented below. 


\subsection{Denmark}

Dependent Variable: GDP_grate; Method: Least Squares; Sample: 1971 - 2017

Number of observations: 47

\begin{tabular}{|l|l|l|l|l|}
\hline Variable & Coefficient & Std. Error & t-Statistic & Prob. \\
\hline Log(CIT) & 0.038047 & 0.017120 & 2.222329 & 0.0314 \\
\hline Log(PIT) & -0.094669 & 0.022888 & -4.136266 & 0.0002 \\
\hline C & 0.843331 & 0.117999 & 7.146937 & 0.0000 \\
\hline R-squared & 0.763452 & Mean dependent var & 0.059504 \\
\hline Adjusted R-squared & 0.752700 & S.D. dependent var & 0.043322 \\
\hline S.E. of regression & 0.021544 & Akaike info criterion & -4.775762 \\
\hline Sum squared resid & 0.020422 & Schwarz criterion & -4.657667 \\
\hline Log likelihood & 115.2304 & Hannan-Quinn criter. & -4.731322 \\
\hline F-statistic & 71.00431 & Durbin-Watson stat & 1.752713 \\
\hline Prob(F-statistic) & 0.000000 & \multicolumn{2}{|l}{}
\end{tabular}

Figure 9: The econometric results for Denmark

Following the tests made and given the fact that the independent variables SSC and VAT were found as not significant from the econometric point of view, we have eliminated them from the model and we proceed to logarithm the remaining independent variables. Therefore, the final equation resulted is:

$$
\text { GDP_grate }=0.84+0.03 \times \log (\mathrm{CIT})-0.09 \times \log (\mathrm{PIT})
$$

In terms of economic interpretation, the econometric model obtained tells us that an increase of $1 \%$ of CIT determines an increase of 0.03 percentage points ("p.p.") of GDP_grate, while an increase of $1 \%$ of PIT determines a decrease of 0.09 p.p. of GDP_grate. For each variable, the interpretation is valid given that all other variables included remain constant.

\subsection{Finland}

Dependent Variable: GDP_grate; Method: Least Squares; Sample: 1971 - 2017

Number of observations: 47

\begin{tabular}{|l|l|l|l|l|}
\hline Variable & Coefficient & Std. Error & t-Statistic & Prob. \\
\hline CIT & $1.35 \mathrm{E}-05$ & $4.79 \mathrm{E}-06$ & 2.828677 & 0.0071 \\
\hline PIT & $-2.25 \mathrm{E}-05$ & $5.27 \mathrm{E}-06$ & -4.281601 & 0.0001 \\
\hline VAT & $1.94 \mathrm{E}-05$ & $6.83 \mathrm{E}-06$ & 2.847921 & 0.0067 \\
\hline C & 0.183270 & 0.015377 & 11.91834 & 0.0000 \\
\hline R-squared & 0.646459 & Mean dependent var & 0.071085 \\
\hline Adjusted R-squared & 0.621794 & S.D. dependent var & 0.062848 \\
\hline S.E. of regression & 0.038650 & Akaike info criterion & -3.587253 \\
\hline Sum squared resid & 0.064236 & Schwarz criterion & -3.429794 \\
\hline Log likelihood & 88.30044 & Hannan-Quinn criter. & -3.528000 \\
\hline F-statistic & 26.20890 & Durbin-Watson stat & 1.190121 \\
\hline Prob(F-statistic) & 0.000000 & \multicolumn{2}{l}{} \\
\cline { 1 - 3 }
\end{tabular}

Figure 10: The econometric results for Finland

For the same reasons as those mentioned in case of Denmark, we have eliminated the SSC. Therefore, the final equation resulted is:

$$
\text { GDP_grate }=0.18+1.35 \times \text { CIT }-2.25 \times \text { PIT }+1.94 \times \text { VAT }
$$

In terms of economic interpretation, the econometric model obtained tells us that, in terms of direct taxation, an increase of one unit (1,000 million EUR) in CIT determines an increase of 
1.35 p.p. of GDP_grate, while an increase of one unit in PIT determines a decrease of 2.25 p.p. of GDP_grate. In terms of indirect taxation, an increase of one unit in VAT leads to an increase of 1.94 p.p. of GDP_grate. For each variable, the interpretation is valid given that all other variables included remain constant.

\subsection{Norway}

Dependent Variable: GDP_grate; Method: Least Squares; Sample: 1971 - 2017

Number of observations: 47

\begin{tabular}{|l|l|l|l|l|}
\hline Variable & Coefficient & Std. Error & t-Statistic & Prob. \\
\hline Log(CIT) & 0.034397 & 0.011006 & 3.125258 & 0.0031 \\
\hline Log(PIT) & -0.093108 & 0.019443 & -4.788849 & 0.0000 \\
\hline C & 0.773266 & 0.117233 & 6.596092 & 0.0000 \\
\hline R-squared & 0.502081 & Mean dependent var & 0.073539 \\
\hline Adjusted R-squared & 0.479448 & S.D. dependent var & 0.053126 \\
\hline S.E. of regression & 0.038330 & Akaike info criterion & -3.623478 \\
\hline Sum squared resid & 0.064644 & Schwarz criterion & -3.505384 \\
\hline Log likelihood & 88.15174 & Hannan-Quinn criter. & -3.579039 \\
\hline F-statistic & 22.18386 & Durbin-Watson stat & 1.816978 \\
\hline Prob(F-statistic) & 0.000000 & \multicolumn{2}{l|}{} \\
\cline { 2 - 4 }
\end{tabular}

Figure 11: The econometric results for Norway

We have eliminated the independent variables SSC and VAT and we proceed to logarithm the remaining independent variables. The final equation resulted is:

$$
\text { GDP_grate }=0.77+0.03 \times \log (\mathrm{CIT})-0.09 \times \log (\mathrm{PIT})
$$

In terms of economic interpretation, the econometric model obtained tells us that an increase of $1 \%$ of CIT determines an increase of 0.03 p.p. of GDP_grate, while an increase of $1 \%$ of PIT determines a decrease of 0.09 p.p. of GDP_grate. For each variable, the interpretation is valid given that all other variables included remain constant.

\subsection{Sweden}

Dependent Variable: GDP_grate; Method: Least Squares; Sample: 1971 - 2017

Number of observations: 47

\begin{tabular}{|l|l|l|l|l|}
\hline Variable & Coefficient & Std. Error & t-Statistic & Prob. \\
\hline Log(PIT) & 0.094097 & 0.033097 & 2.843040 & 0.0068 \\
\hline Log(VAT) & -0.096804 & 0.023838 & -4.060837 & 0.0002 \\
\hline C & 0.023509 & 0.141385 & 0.166273 & 0.8687 \\
\hline R-squared & 0.648831 & Mean dependent var & 0.065280 \\
\hline Adjusted R-squared & 0.632869 & S.D. dependent var & 0.042670 \\
\hline S.E. of regression & 0.025854 & Akaike info criterion & -4.410976 \\
\hline Sum squared resid & 0.029412 & Schwarz criterion & -4.292882 \\
\hline Log likelihood & 106.6579 & Hannan-Quinn criter. & -4.366536 \\
\hline F-statistic & 40.64792 & Durbin-Watson stat & 1.533790 \\
\hline Prob(F-statistic) & 0.000000 & &
\end{tabular}

Figure 12: The econometric results for Sweden

We have eliminated the independent variables SSC and CIT and we proceed to logarithm the remaining independent variables. The final equation resulted is:

$$
\text { GDP_grate }=0.02+0.09 \times \log (\mathrm{PIT})-0.09 \times \log (\mathrm{VAT})
$$


In terms of economic interpretation, the econometric model obtained tells us that an increase of $1 \%$ of PIT determines an increase of 0.09 p.p. of GDP_grate, while an increase of $1 \%$ of VAT determines a decrease of 0.09 p.p. of GDP_grate. For each variable, the interpretation is valid given that all other variables included remain constant.

The case of Sweden is an exceptional one, with analyzes showing different results from the other countries (and from the research provided by the specialized literature). However, from an extended economic point of view, we could perceive this result in the sense that PIT does not necessarily influence the economic growth, but that PIT is less harmful to economic growth. Going forward, we could say that the case of Sweden could generate a positive answer to the question: higher taxes, higher wealth? As regards the negative relationship between VAT and economic growth, this may indicate that Sweden has an economy that is not necessarily based on consumption. Subsequently, such fact can reveal the stability of the Swedish economy.

As far as the econometric testing is concerned, we have made a few points in the following.

We note that in all the cases, the output records R-squared and Adjusted R-squared values of above 0.5 , meaning that the independent variables included in the models explain in proportion of over $50 \%$ the dependent variable GDP_grate.

In terms of parameter testing, we note that the variables included record values of Prob. lower than $0.05(5 \%)$, so we can argue that all the variables included significantly influence the dependent variable. Furthermore, in order to test each model as a whole, since Prob. of F-statistic is 0 in all the cases, lower than 5\%, we have the arguments to sustain that the regression models are valid.

\section{CONCLUSIONS, DISCUSSIONS AND LIMITATIONS}

The analyzes performed proved that in all cases the tax elements CIT and PIT have a significant influence on the economic growth/wealth of citizens.

Throughout the econometric analysis, we have concluded that:

- CIT has a positive influence, while PIT has a negative influence on GDP_grate in the case of Denmark, Finland and Norway;

- Unusual situation in the case of Sweden, where PIT has positive influence on GDP_ grate and VAT a negative influence;

- In the case of Finland, the VAT has a positive influence on GDP_grate.

The models performed in this paper has strictly targeted the influence of taxation on economic growth (wealth of citizens) and additional econometric tests could be carried out to strengthen the results.

As another conclusion, during the analyzes, we observed that all the tax systems of Nordic countries are similar in terms of the evolution of the fiscal/economic variables included. Consequently, we can distinguish a cluster composed of Scandinavian countries in terms of the characteristics of the tax systems, but also of the economy as a whole.

Further, our contribution complements a series of similar analyses (for other countries) and the results allow a comparison with other tax systems. Our results generally confirm the results highlighted in the literature, with the exception of Sweden for which we obtained a unique result. 


\section{REFERENCES}

[1] Bloom, C. C. (1955). State and Local Tax Differentials and the Location of Manufacturing. Bureau of Business and Economic Research;

[2] Thompson, W. R., Mattila, J. M. (1959). An Econometric Model of Postwar State Industrial Development. Wayne State University Press;

[3] Carlton, D. W. (1979). Why new firms locate where they do: An econometric model Interregional Movements and Regional Growth. The Urban Institute;

[4] Helms, L. J. (1985). The Effect of State and Local Taxes on Economic Growth: A Time Series Cross Section Approach, The Review of Economics and Statistics, 67, 574-82;

[5] Burgess, R., Stern, N. (1993). Taxation and Development, Journal of Economic Literature, 31(2), 762-830;

[6] Obreja, L., Brasoveanu, I. (2008). The Correlation between Fiscal Policy and Economic Growth, Theoretical and Applied Economics, 11(528), 51-59;

[7] Romer, C., Romer, D. (2010). The Macroeconomic Effects of Tax Changes: Estimates Based on a New Measure of Fiscal Shocks. American Economic Review, 100(3), 763-801;

[8] Nálepová, V., (2017). Affects corporate taxation economic growth? - Dynamic approach for OECD Countries. European Journal of Business Science and Technology, 3(2), 132-147;

[9] Widmalm (2001), Tax Structure and Growth: Are Some Taxes Better Than Others? Public Choice 107 (3/4), 199-219;

[10] Stoilova \& Patonov (2012), An empirical evidence for the impact of taxation on economy growth in the European Union. Book of Proceedings - Tourism and Management Studies International Conference Algarve 2012(3), 1031-1039;

[11] Szarowská (2013), Effects of taxation by economic functions on economic growth in the European Union. Proceedings of the 6th International Scientific Conference: Finance and the performance of Firms in Science, Education and Practice. Zlin: Tomas Bata University, 746-758;

[12] Kosketa \& Viren (1994). Taxation and Household Saving in Open Economies: Evidence from the Nordic Countries. The Scandinavian Journal of Economics 96(3), Tax Policy in Small Open Economies, 425-441;

[13] Livingston (2016). The Nordic model of taxation and its influence in North America: Image and Reality. Nordic Tax Journal 2016(2), 77-86;

[14] Stoilova (2017) Tax structure and economic growth: Evidence from the European Union. Contaduria y Administracion 62(2017), 1041-1057;

[15] http://www.ey.com/gl/en/services/tax/global-tax-guide-archive

[16] http://stats.oecd.org/ 